\title{
ひも状ミセル水溶液の非線形レオロジー
}

\section{Nonlinear Rheology of Aqueous Solutions of Thread-like Micelles}

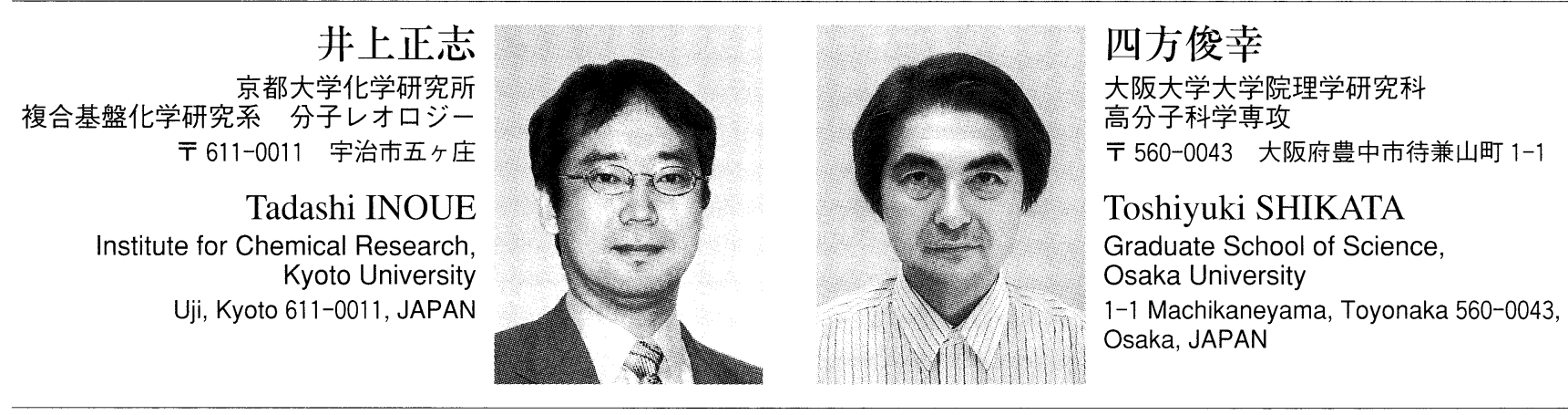

論文要旨：臭化セチルトリメチルアンモニウム $(\mathrm{CTAB})$ とサリチル酸ナトリウム $(\mathrm{NaSal})$ からなるひも状 ミセルの水溶液の非線形粘弾性について調べた。CTAB 濃度は $0.1 \mathrm{~mol} \mathrm{l}^{-1}$ とし NaSal 濃度を 0.07 から 0.4 $\mathrm{mol} \mathrm{l}^{-1}$ まで変えた。いずれの試料においても，線形粘弾性は単一緩和で記述できた。また，いずれの試料に 拈いても，ずり流動印可後のずり応力 $\sigma$ と第一法線応力差 $N_{1}$ の成長に扔いて，ずり速度が緩和時間の逆数 より大きいある臨界ずり速度を超えた場合に，ひずみ硬化が観測された。ひずみ硬化領域では $\sigma$ と $N_{1}$ の間 には単純な弾性体の関係が成立し，ひずみ硬化は，弾性率がひずみ依存すると考えればよいことがわかった。 弾性率のひずみ依存性は，鎖の伸びきりを考虑した網目理論で記述できた。伸びきり挙動から鎖のセグメン 卜を評価することができた。定加重印可時のクリープ応答についても測定した。その結果，加重が線形弾性 率より大きくなると，回復コンプライアンスが増加し，流動によって溶液構造が変化していることが示唆さ れた。

Abstract: Nonlinear rheology of aqueous solutions of thread-like micelles of cetyltrimethylammonium bromide (CTAB) and sodium salicylate (NaSal) were investigated. The concentration of CTAB was fixed at $0.1 \mathrm{~mol} \mathrm{l}^{-1}$, and the concentration of NaSal was varied from 0.07 to $0.4 \mathrm{~mol} \mathrm{l}^{-1}$. For all test solutions, dynamic moduli were described with the Maxwell model having a single relaxation time, $\tau$. Time evolutions of the shear stress, $\sigma$, and the first normal stress difference, $N_{1}$, after inception of the steady shear flow were measured. For all test solutions, strain-hardening was observed and $\sigma$ and $N_{1}$ diverged at a certain strain when the shear rate, $\gamma$, exceeded a critical rate being larger than $\tau^{-1}$. A simple relationship for elastic solids, $N_{1} / \sigma=\gamma$ with $\gamma$ being the strain imposed by shear flow, held for all the solutions in the strain-hardening regime. The strain-hardening was attributable to the strain dependent shear modulus and well described with the network theory considering finite extensibility of network strands. The segment size of network strand was successfully determined. Creep response of the solutions was also measured. At higher stress level than the plateau modulus, recoverable compliance was considerably increased, suggesting shear-induced structural changes.

Key words: Thread-like Micelles, Nonlinear Rheology, Strain Hardening, Finite Extensibility, Entanglements

\section{1 緒言}

ある種の界面活性剤は，水溶液中でひも状のミセルを

連絡者：井上正志

E-mail : tinoue@scl.kyoto-u.ac.jp
形成する。よく知られた系としては，臭化セチルトリメ チルアンモニウム $\mathrm{C} T \mathrm{TAB}$ とサリチル酸ナトリウム NaSal の混合系が挙げられる。その他，塩化セチルトリ メチルアンモニウム CTAC，臭化セチルピリジウムアン モニウム $\mathrm{CPyB}$ ，塩化セチルピリジゥムアンモニウム 
$\mathrm{CPyB}$ といった界面活性剂と $\mathrm{NaSal}$ の混合系も知られて いる。このような系では, カチオン性界面活性剤とサリ チル酸イオンが $1: 1$ のコンプレックスを形成して，ひ も状ミセルを形成していると考えられている ${ }^{1-4)}$ 。ひも状 ミセルでは，生成・解離が熱的に可能で，絶えず長さが 変化しているものと考える研究者もいる。したがって, リビングポリマーと呼ばれる場合もある5)。

高分子溶液との類推から, 濃度が低い（1～5 mM; $\phi \approx$ 0.002）場合には，ひも状ミセルは孤立し，いわゆる希薄 溶液になると考えられている。希薄溶液では，ミセルは 他のミセルと接触する確率は低い。このような場合, ミ セルが切断される時間 (寿命) が十分長ければ，粘弾性 には高分子的な緩和モードが観測されると想像される が，この類推は実験的に確かめられている ${ }^{6)}$ 。しかしな がら，速い流動条件の場合には，高分子の希薄溶液との 類似性は成立せず，ひも状ミセル系はきわめて特異な流 動挙動を示す ${ }^{7-10)}$ 。高分子の希薄溶液系では，粘度はず り速度にほとんど依存しないと考えてよい。しかしなが ら，ひも状ミセル系では，あるずり速度を境にして，粘 度が数倍増加し，この現象は流動硬化と呼ばれる。流動 硬化が観測されるずり速度域では，高い粘度值を示す定 常状態に達するのに長時間を要すること，あるいは，定 常状態が不規則に振動する場合があることなどが知られ ている。このような現象には，流動によってミセルの長 さが成長すること列が関係していると考えられている。 Pine らは ${ }^{12,13)}$ ，時間依存性を示す高い弾性を持つゲル状 の構造の存在を実験的に示した。この構造は流動誘起構 造 SIS と呼ばれる。ミセル濃度が高い場合（準濃厚溶 液）でも，流動誘起光散乱や高分子系よりも弱い流動軟 化性から，SISが存在すると考えられているが年，その 詳細はあまり明らかになっていない。特にSIS という言 葉が意味する内容は，研究者や対象とする系によってか なり違っているものと思われる。

$\mathrm{CTAB} / \mathrm{NaSal}$ の準濃厚溶液では，ひも状ミセルがか らみ合って，顕著な粘弾性を示すようになる。このよう な場合，粘弾性緩和が単一指数型で記述できることが知 られている。この粘弾性緩和に関して, 幽霊網目のごと くミセルが通りぬける過程が関与していると考えられて いる ${ }^{1-4)}$ 。また，サリチル酸イオン $\mathrm{Sal}$ のモル濃度 $C_{\mathrm{S}}$ を 変えた実験から，Sal が通り抜け過程の触媒として作用 していると考えられている。

準濃厚溶液の速い流れ場での非線形レオロジーは，四

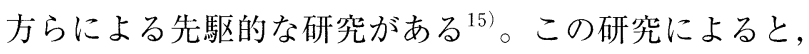
界面活性剂のモル濃度 $C_{\mathrm{D}}$ が $C_{\mathrm{S}}$ の以下の場合 $\left(C_{\mathrm{D}}<\right.$ $C_{\mathrm{S}}$ ), 高分子のからみ合い溶液に類似した流動軟化が観 測される。すなわち, 定常粘度があるずり速度を境とし
て，ずり速度の増加とともに減少する。一方， $C_{\mathrm{D}} \sim C_{\mathrm{S}}$ の場合には，ひずみ硬化のような現象を示す。ひずみ硬 化は，高分子系では観測されることが珍しく，ひも状ミ セル系でのその分子論的起源については明らかにされて いない。以上のように，ひも状ミセル系の非線形レオロ ジーには未解明の部分が多く, 本研究ではひも状ミセル 系で非線形レオロジーの精査を目的として，定常流印可 後の応力成長 ${ }^{16)}$ と高応力下でのクリープ挙動 ${ }^{17)}$ に関する 研究について総括する。

\section{2 実験}

臭化セチルトリメチルアンモニウム（CTAB，和光純 薬工業(株)）は，アセトンノメタノールを用いて再結晶 した後，使用した。サリチル酸ナトリウム（NaSal，和 光純薬工業(株)）はそのまま使用した。所定量の CTAB および NaSal を蒸留水に溶解させて試料溶液とした。試 料コードと溶液濃度を Table 1 に示す。

Table 1 Concentration and Viscoelastic Parameters for Test Solutions.

\begin{tabular}{lclcrc}
\hline Sample Code & $\begin{array}{c}C_{\mathrm{D}} \\
\mathrm{mol} \mathrm{l}^{-1}\end{array}$ & $\begin{array}{c}C_{\mathrm{S}} \\
\mathrm{mol} \mathrm{1} \mathrm{l}^{-1}\end{array}$ & $\begin{array}{c}\tau \\
\mathrm{S}\end{array}$ & $\begin{array}{r}G_{\mathrm{N}} \\
\mathrm{Pa}\end{array}$ & $\gamma_{\mathrm{F}}$ \\
\hline CTAB1 & 0.1 & 0.15 & 4.4 & 51 & 4.3 \\
CTAB2 & 0.1 & 0.3 & 4.6 & 48 & 5.2 \\
CTAB3 & 0.1 & 0.07 & 47 & 40 & 4.2 \\
CTAB4 & 0.1 & 0.4 & 0.95 & 48 & 6.2 \\
CTAB5 & 0.2 & 0.14 & 4.6 & 140 & 2.9 \\
CTAB6 & 0.05 & 0.035 & 530 & 11 & 6.2 \\
\hline
\end{tabular}

粘弾性測定には，レオメトリック社製 ARESに自作 の溶媒蒸発防止装置を装着して用いた。クリープおよび クリープ回復には，レオメトリック社製 SR5000を使用 した。

\section{3 結果}

$3 \cdot 1$ 線形粘弾性：Fig. 1 に CTAB/ $\mathrm{NaSal}$ 水溶液の動 的粘弾性測定結果を示す。動的粘弾性の測定結果は, 既 報の通り単一指数型の緩和を示した。次式に示す単一緩 和でフィッティングすることにより, 緩和時間 $\tau$ と平坦 弾性率 $G_{\mathrm{N}}$ を求めた。

$$
G^{*}(\omega)=G^{\prime}(\omega)+i G^{\prime \prime}(\omega)=G_{N} \frac{i \omega \tau}{1+i \omega \tau}
$$

得られた $\tau$ と $G_{\mathrm{N}}$ を Table 1 に示す。なお，高周波数領

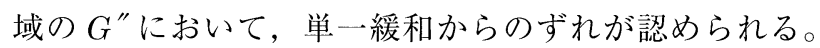
網目の内部モードによるものと考えられるが，ここでは 立ち入らない。

$3 \cdot 2$ 流動開始後の応力成長：Fig. 2 に試料 CTAB1 $\left(C_{\mathrm{D}}=0.1 \mathrm{~mol} \mathrm{l}^{-1}, C_{\mathrm{S}}=0.15 \mathrm{~mol} \mathrm{l}^{-1}\right)$ および試料 CTAB4 $\left(C_{\mathrm{D}}=0.1 \mathrm{~mol} \mathrm{l}^{-1}, C_{\mathrm{S}}=0.4 \mathrm{~mol} \mathrm{l}^{-1}\right)$ のずり応 
力成長関数 $\eta^{+}(t)$ の時間依存性を示す ${ }^{12)}$ 。 $\eta^{+}(t)$ のずり 速度依存性は，3種類に分類することができる。第一 は, ずり速度 $\dot{\gamma}<0.1 \mathrm{~s}^{-1}$ での線形の挙動で, 動的粘弾 性測定から求めた $\tau$ と $G_{\mathrm{N}}$ から計算した $\eta^{+}{ }_{\mathrm{L}}$ （図中） と一致する。

$$
\eta^{+} \mathrm{L}(t)=G_{\mathrm{N}} \tau\left[1-\exp \left(-\frac{t}{\tau}\right)\right]
$$

第二は流動軟化型の挙動で, $\dot{\gamma} / \mathrm{s}^{-1}=0.3\left(\sim \tau^{-1}\right)$ で は， $\eta^{+}$にオーバーシュートが観測され，定常值は線形の 值より小さくなって, 非線形性が観測される。このずり 速度では, $t>\tau$ で, $\eta^{+} \leqq \eta^{+}$である。塩濃度が高い試 料 CTAB2 の場合, 流動軟化が幅広いずり速度の領域で 観測されることがわかる。

第三は，ひずみ硬化型の挙動で， $\dot{\gamma} / \mathrm{s}^{-1} \geqq 0.5$ では, ある時間以降では $\eta^{+}(t)>\eta^{+}{ }_{\mathrm{L}}$ となって, 急激な立ち上 がりが観測される。その後, 極大を示して急減少する が, この減少は試料のジグからのはみ出し (破壊) に起 因し，流動不安定化もしくは破壞によるものである。極 大が生じるひずみ $\gamma_{\mathrm{F}}$ は, 高ひずみ速度の領域では一定 值（～4）となって， $\eta^{+}$の立ち上がりはひずみに由来す ると考えられる。同様の挙動（線形，流動軟化，ひずみ 硬化）は, いずれの試料に扔いても, 法線応力成長関数 にも観測された ${ }^{16)}$ 。

初期の法線応力 $N_{1}$ の研究では弾性体の理論を考慮し て, 次式によって定義される有效弾性率 $G_{\text {eff }}$ と有効ひず み $\gamma_{\text {eff }}$ が利用されている

$$
\begin{aligned}
& \sigma=G_{\text {eff }} \gamma_{\text {eff }} \\
& N_{1}=G_{\text {eff }} \gamma_{\text {eff }}^{2}
\end{aligned}
$$

$\gamma_{\text {eff }}$ は

$$
\gamma_{\text {eff }}=\frac{N_{1}}{\sigma}=\frac{\Psi_{1}}{\eta} \dot{\gamma}
$$

から求めることができる。

$\gamma_{\text {eff }}$ と外部ひずみ $\gamma$ の比較を Fig. 3 に示す。ここでは, 緩和の効果を除くため， $\gamma_{\mathrm{eff}}$ を $\dot{\gamma} て ゙$ 除してある。参考の ために, 線形粘弾性のパラメーターを用いてロッジ方程 式 ${ }^{18)}$ から計算した曲線も示す。計算結果では, $\gamma_{\text {eff }} / \dot{\gamma}$ は 短時間領域では, 時間に比例して増加して, $t>\tau$ 以降 では一定となる。低速での実験結果はこの線に一致し た。

興味深い点は，高速度の流動下において観測された $\eta^{+}(t)>\eta^{+}{ }_{\mathrm{L}}$ の挙動において, $\gamma_{\mathrm{eff}} \dot{\gamma}$ は, 時間に比例して いる点である。このことは， $\gamma_{\mathrm{eff}}=\gamma$ を意味し，ひずみ 硬化 $\left(\eta^{+}(t)>\eta^{+}{ }_{\mathrm{L}}\right)$ の現象に扔いても，理想弾性体の 関係式が成立していること示している。この結果は, $\eta^{+}(t)$ と $\Psi^{+}(t)$ で観測された急激な立ち上がりが， $G_{\text {eff }}$ の変化 に起因していると考えることができる。

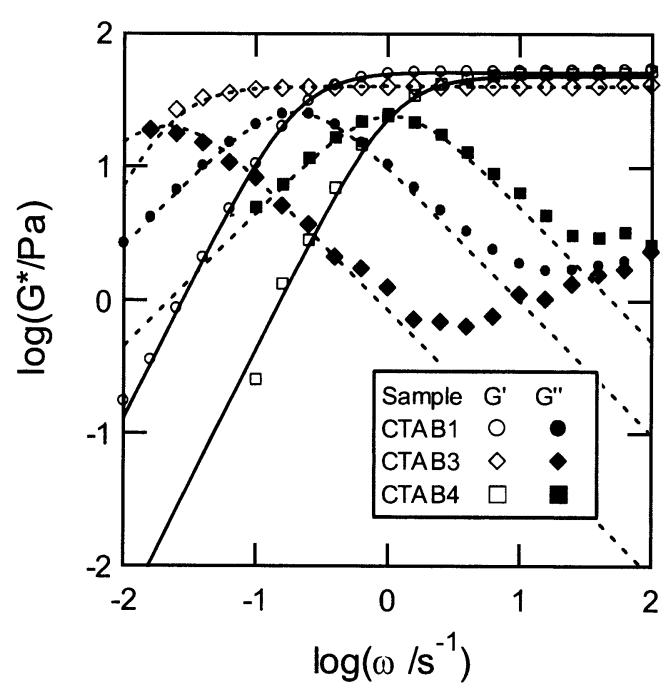

Fig. 1 Complex Shear Modulus for CTAB1, CTAB3, and CTAB4. Lines represent equation (1).
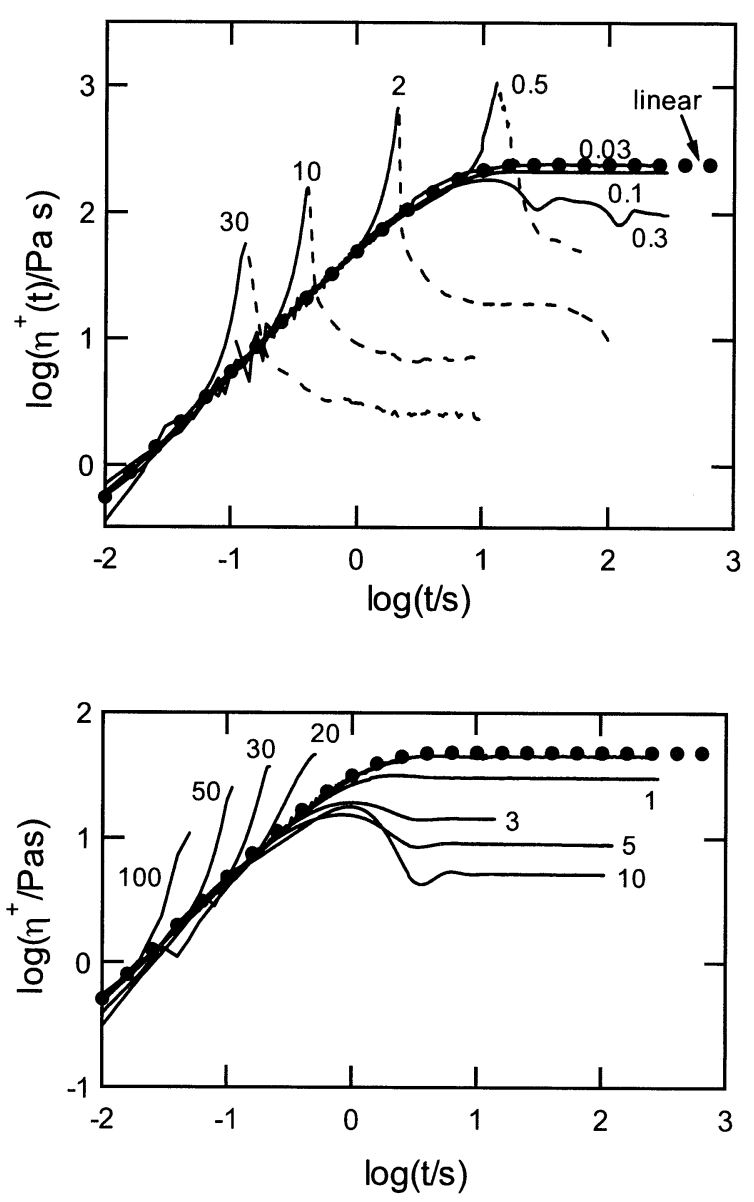

Fig. 2 Viscosity Growth Function for CTAB1 (Top) and CTAB4 (Bottom). Numbers indicate shear rate $\left(\mathrm{s}^{-1}\right)$. 


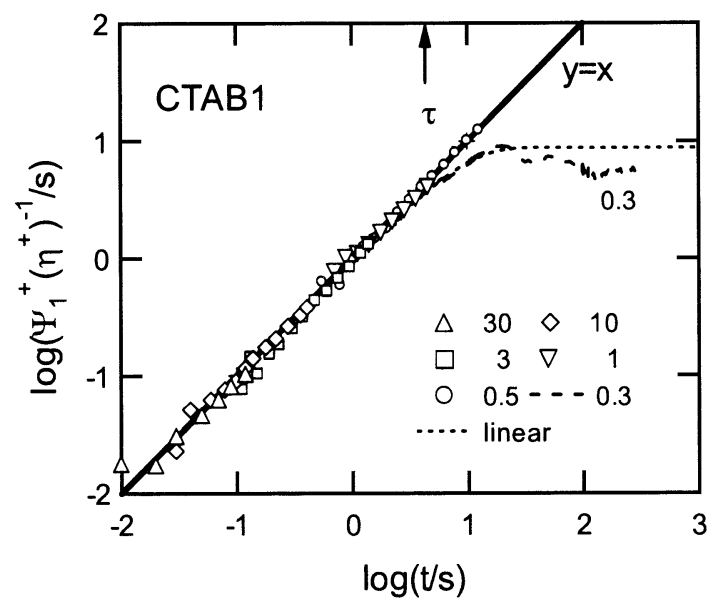

Fig. 3 Time Dependence of Effective Strain for CTAB1. Numbers indicate shear rate $\left(\mathrm{s}^{-1}\right)$.

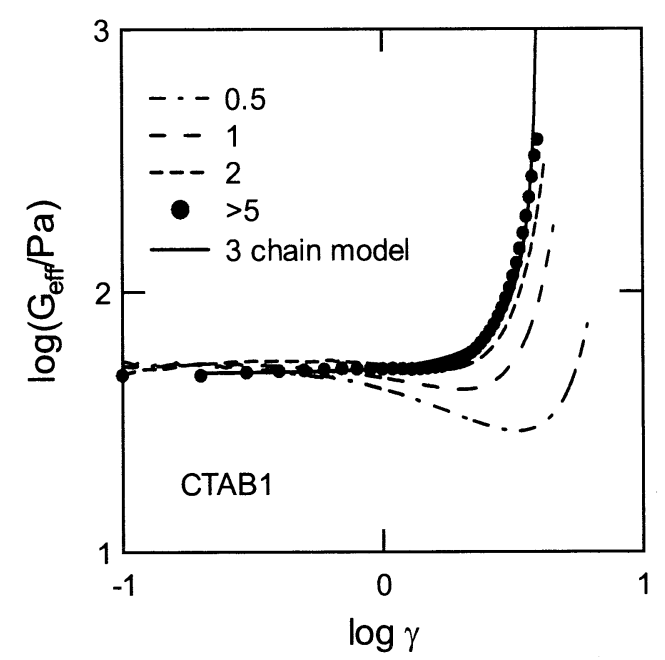

Fig. 4 Strain Dependence of Effective Modulus for CTAB1. Numbers indicate shear rate $\left(\mathrm{s}^{-1}\right)$.

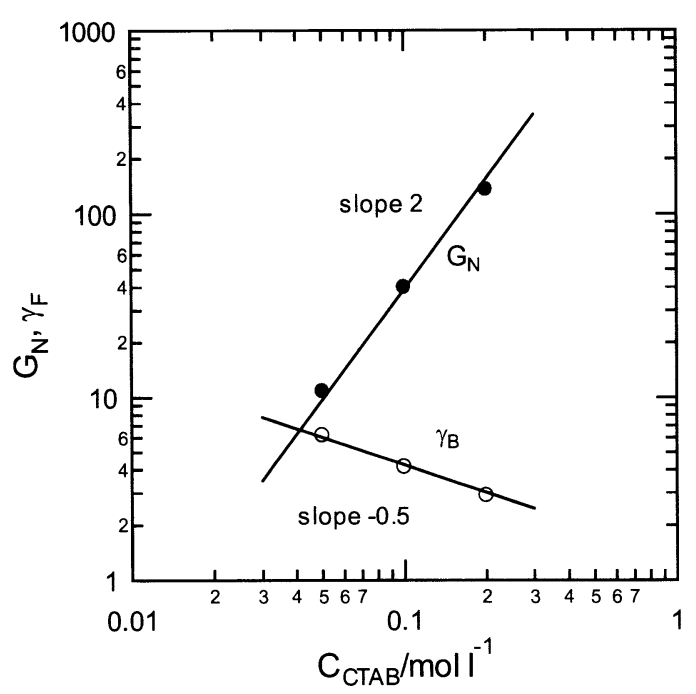

Fig. 5 Concentration Dependence of Effective Modulus and Break Strain.
高速度の流動下について $G_{\text {eff }}(\gamma, \dot{\gamma})=\eta(\gamma, \dot{\gamma}) / t$ として $G_{\text {eff }}$ のひずみ依存性を求めると, ずり速度が増加すると $G_{\mathrm{eff}}$ の挙動は収斂することがわかった。この結果を Fig. 4 に示す。ずり速度 $5 \mathrm{~s}^{-1}$ 以上では， $G_{\mathrm{eff}}$ はずり速度に依 存性しない。このようにして求めた $G_{\mathrm{eff}}$ を, 以下では $G_{\mathrm{eff}}(\gamma, \infty)$ と表記することにする。Fig. 1 から $\omega / \mathrm{s}^{-1}<$ 100 では, 網目内部の運動はほとんど見えないことがわ かる。したがって, ずり速度が $100 \mathrm{~s}^{-1}$ 程度までは, 架 橋点間の鎖は, 可能な配置をすべて取り得る平衡網目と 見なせることが予想される。したがって，Fig. 4 は平衡 網目の応答として考えてよいであろう。

$G_{\text {eff }}(\gamma, \infty)$ は $\gamma=2$ 付近から急増し, $\gamma=4$ 付近で発散す るように見える。このような $G_{\mathrm{eff}}(\gamma, \infty)$ の挙動は, 有限 長さを持つ鎖の伸びきりを考慮した平衡網目の弾性率と 似ている。鎖の統計をランジバン関数で表した 3 本鎖モ デル (three chain model) ${ }^{19)}$ で計算した弾性率を Fig. 4 に 示す。モデルと実験值の一致は良好であり，弾性率のひ ずみ依存性が，鎖の伸びきりに起因していることを強く 示唆する。

このモデルによれば，弾性率が発散するひずみは，網 目を形成する鎖のセグメント数の平方根に一致する。こ の関係を利用すると，ひも状ミセルのセグメントの大き さを推定することができる。計算の結果，セグメントを 構成する CTAB 分子の数は 240 個程度となり，ひも状 ミセルの断面が 10 個程度の CTAB 分子から形成されて いるものとすると， 24 層分となる ${ }^{16)}$ 。

網目の伸びきり挙動をより調べるために， $C_{\mathrm{D}}: C_{\mathrm{S}}=$ $1: 0.7$ に固定して, $\mathrm{G}_{\mathrm{eff}}(\gamma, \infty)$ の濃度依存性を調べた。こ の結果を Fig. 5 に示す。微小ひずみでの弾性率 $G_{\mathrm{N}}$ は $C_{\mathrm{D}}$ のほぼ 2 乗に比例していることがわかる。また， $G_{\mathrm{eff}}(\gamma, \infty)$ の極大 (発散)が観測されるひずみ $\gamma_{\mathrm{F}}$ の濃度依存性は

$$
\gamma_{\mathrm{F}} \propto C_{\mathrm{D}}{ }^{-0.5}
$$

であった。この結果は，CTAB 濃度が変化してもセグメ ントの大きさは変わらず，弾性率の発散が網目の希釈で 説明できることを意味している。

3.3 定常状態：Fig. 6 に試料 CTAB2 の定常状態で のずり応力 $\sigma$ と法線応力 $N_{1}$ のずり速度依存性を示す。 高いずり速度領域では，。はずり速度によらずほぼ一定 となっているが， $N_{1}$ はずり速度とともに増加している。 $\sigma$ が定となる領域に関しては, ずり速度が異なる二つ の層に分離するシアーバンド構造の存在が理論的に予言 されており，また実験的にも共軸円筒系の装置では，層 状の構造形成が観測されている ${ }^{20,21)}$ 。しかしながら， $N_{1}$ がずり速度とともに増加することから，シアーバンド構 造における二層の法線応力が異なっているものと考えね ばならない。したがって，二層の間で $N_{1}$ のバランスが 
とれないため, 定常的にシアーバンド構造が存在できる か疑問である。光学的手法による観察では, 非定常的な 複雑な流れが観測されているが22)，本実験における目視 による観察では不安定な流動を起こしているようには見 えなかった。

$3 \cdot 4$ クリープおよびクリープ回復：Fig. 7 にクリー プの測定結果の一例を示す。短時間領域では，装置の慣 性のため, 弱い振動が観測されている。印加応力 $\sigma_{0}$ が 低い場合, 線形粘弾性から予想されるようにマックス ウェル型のクリープであることがわかる。

$$
J(t)=J_{\mathrm{r}}(t)+\frac{t}{\eta}=J_{\mathrm{e}}+\frac{t}{\eta}
$$

また， $\sigma_{0}$ を除くと $J_{\mathrm{r}}(t)$ を求めることができるが， $J_{\mathrm{r}}(t)$

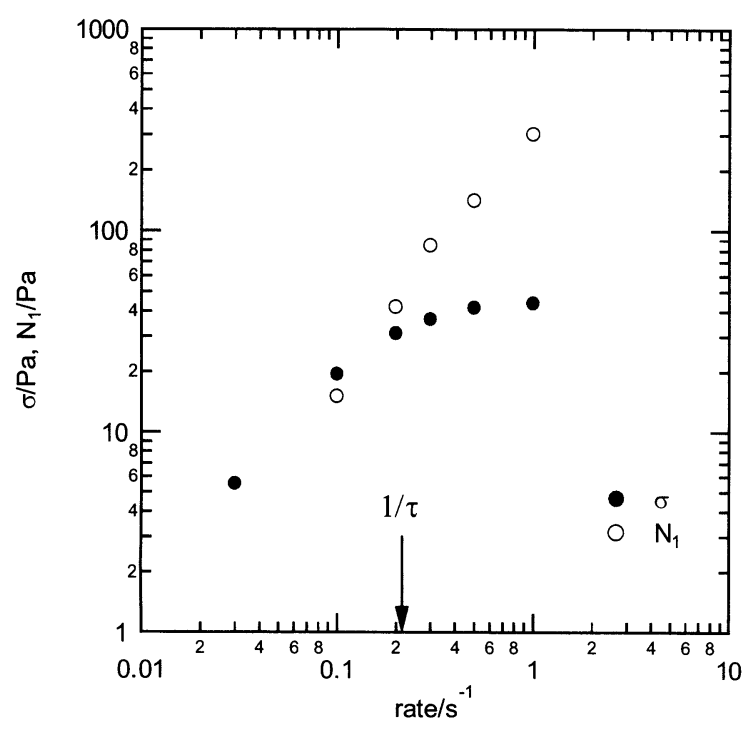

Fig. 6 Steady State Viscosity and First Normal Stress Coefficient for CTAB2.

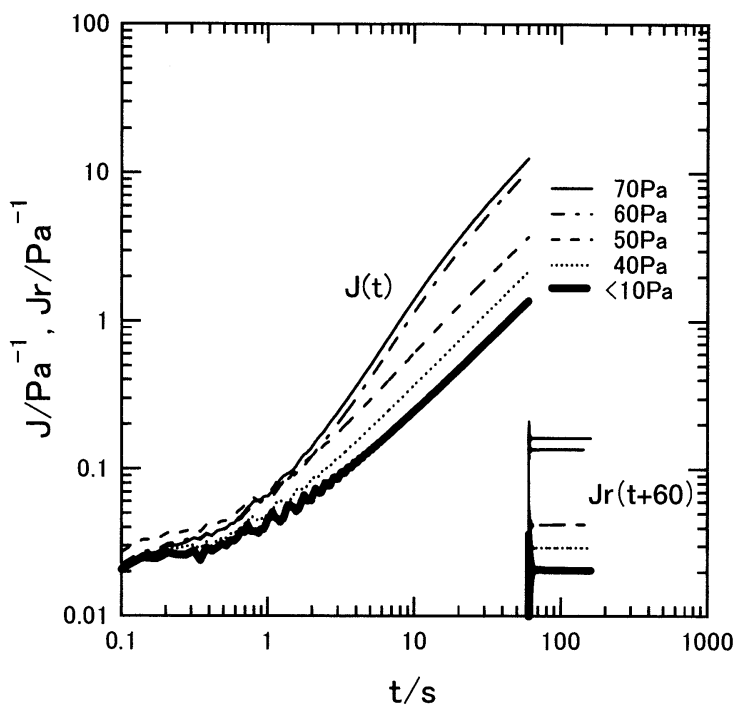

Fig. 7 Stress Dependence of Creep Compliance for CTAB4.
は時間に依存せず，次式で記述できることがわかる。

$$
J_{\mathrm{r}}(t)=J_{\mathrm{e}}
$$

応力が低く線形性が成立する範囲では, $J(t), J_{\mathrm{r}}(t)$ は $\sigma_{0}$ に依存しない。応力を増加させると, $\sigma_{0} \sim 50 \mathrm{~Pa} \sim \mathrm{G}_{\mathrm{N}}$ 付近から，線形の挙動からずれることがわかる。四方ら の研究によると, 応力の増加によって, $J(0)$ は小さな る ${ }^{17)}$ 。これは，先に述べた $G_{\mathrm{eff}}$ のひずみ依存性と対応し ているものと考えられる。長時間領域では, $\mathrm{d} J / \mathrm{d} t$ は一 定となって, 定常状態に至り， $\sigma_{0}$ との比から定常粘度 $\eta$ を求めることができる。

一方，高い応力からのクリープ回復でも， $\sigma_{0}$ を除くと 時間に依存せず，（8）式で成立することがわかる。しか しながら， $J_{\mathrm{e}}$ の值は， $\sigma_{0}$ とともに増加しており，溶液 の構造が変化していることを示唆する。

こうして求めた $\eta$ と $\mathrm{J}_{\mathrm{e}}$ を, 定常状態でのずり速度の 関数としてプロットしたものを Fig. 8 に示す。定ずり速 度の実験から求めた $\eta$ と $\Psi_{1}=N_{1} / \dot{\gamma}^{2}$ の結果も併せて示 す。二つの測定による $\eta$ はほぼ一致している。わずかの 差は，測定温度の違いによると考えられる。特筆すべき 点は，定ずり速度の実験では，伸びきりによる不安定化 のために， $\dot{\gamma} / \mathrm{s}^{-1}<10$ でのみ定常状態に至れるのに対 し，クリープ測定では，より高ずり速度領域まで定常状 態に達している点である。すなわち，ずり速度の履歴に よっては，定常状態に達せられない場合があることを意 味する。この結果からも，流動によって内部の構造が変 化していることが示唆される。

クリープ回復過程もマックスウェル型（(7) および (8) 式）で記述できることから，ここでは定常状態での流動 をマックスウェルモデルのパラメーターにずり速度依存 性を持たすことによって非線形化することを考える。言 い換えるなら，流動により構造が変化したものと考え る。マックスウェルモデル（厳密にはロッジモデル）に よると定常状態は，緩和時間 $\tau$ と弾性率 $G_{\mathrm{N}}=1 / J_{\mathrm{e}}$ を用 いて,

$$
\begin{aligned}
& \eta=G_{\mathrm{N}} \tau \quad\left(\tau=\eta J_{\mathrm{e}}\right) \\
& \Psi=G_{\mathrm{N}} \tau^{2}
\end{aligned}
$$

と表される。 $\eta$ と $J_{\mathrm{e}}$ の結果から， $\tau$ を求めた結果を Fig. 8 に示す。 $\tau$ はずり速度によってほとんど変化していな いことがわかる。この $\tau$ と $J_{\mathrm{e}}$ から (10) 式に基づいて計 算した $\Psi_{1}$ を Fig. 8 に示す。実験結果との一致は良好で, 定常状態がマックスウェル型で近似できることを支持す る。このような解析に基づくと, 高ずり速度（高応力） 状態では， $G_{\mathrm{N}}$ が低下することから，からみ合いが減少 することが想像される。 $\tau$ がほとんど変化しない事実か ら，てがミセルのすり抜けによって決まっているとする ならば，このすり抜け過程は流動には影響を受けないこ 


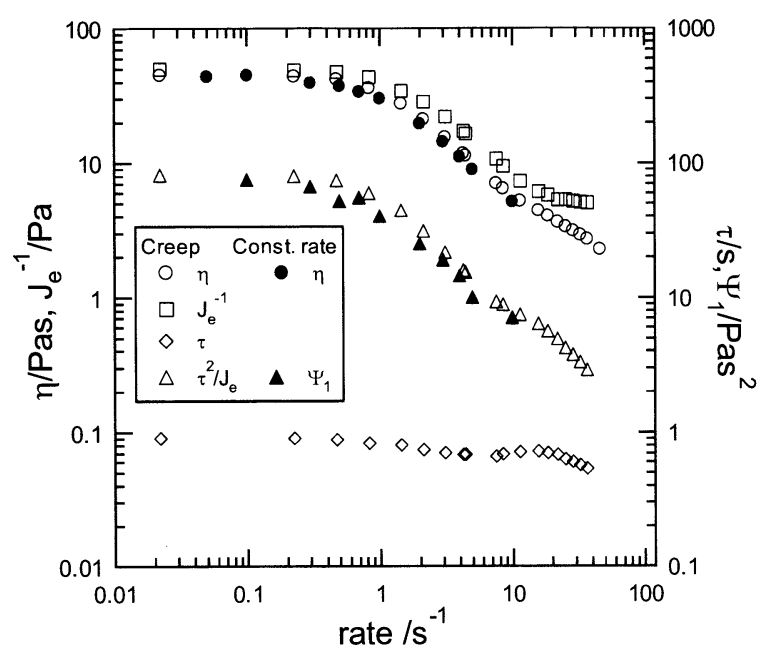

Fig. 8 Recoverable Compliance and Relaxation Time for CTAB4.

とも想像される。以上の考察から流動によってミセルが 配向し，からみ合いが減ったという分子描像が見えてく る。流動方向に配向した液晶的な領域が生成していると 考えてもよいかもしれない。あるいは，速い流動によっ てミセルが幾らか切断されてからみ合いが減少した可能 性も否定できない。

\section{4 結語}

からみ合いひも状ミセル系に，高いずり速度の流れを 与えること，ゲル的に振る舞うことがわかった。このゲ ル的挙動は，鎖の伸びきりを考慮すればうまく説明する ことができた。通常のからみ合い網目では，からみ合い 点ですべりが生じるため, $\dot{\gamma} \sim \tau^{-1}$ 程度のひずみ速度で は，伸びきりは観測されない。したがって，CTAB/ $\mathrm{NaSal}$ 系では，一時的な架橋が形成されていると考える ほうが，非線形粘弾性を説明する上では妥当である。

また，クリープ条件（一定応力）下では, 回復性コン プライアンスが応力とともに減少するものの, 法線応力 とずり応力の応答がマックスウェル的にふるまうことが わかった。今後, このような変化を記述できる構成方程 式の考案が望まれる。

最後に, 本研究の結果に関してコメントをいくつか述 べておく。まず，流動光散乱測定からは，ひも状ミセル 系では高分子系と同様に, 流動による濃度ゆらぎの増大 が示唆されている ${ }^{14,23,24)}$ 。流動光散乱測定装置を作成し て予備的な実験を行ったところ，伸びきり近傍で白濁す ること, また，いわゆるシアーバンド領域では，散乱は さほど強くなく, クリープ測定のみでしか達することが できない高いずり速度領域で，散乱が顕著になることが わかった。伸びきり近傍での白濁は, 網目が溶媒をはき
出すソルベントスクイズと呼ばれる現象 ${ }^{25)}$ 関係してい るかもしれない。しかしながら，伸びきり挙動が網目の 理論でよく記述できることから, 溶媒の吐き出し（solvent squeeze）によってゲル化が生じるのではないよう である。こうした誘導誘起の構造と粘弾性の関係の解明 は今後の研究課題である。

次に, 四方らの定ずり速度実験によると, 定常状態か らの応力の緩和過程は，単一指数型にならず，二つの指 数関数の和として解析されている ${ }^{15)}$ 。これは, 本研究で のクリープデータの解析における仮定と一見すると矛盾 する。しかしながら，鎖の伸びきりが関与している場 合, 分子論的な緩和機構（ミセルのすリ抜けなど）が単 純であっても, 応力緩和過程は単一指数型にならないと 考えられる。ただし，実際に例えば $G_{\text {eff }}$ のひずみ依存性 を用いて応力緩和過程を非線形化する方法を試みると， 定量的にはうまくいかないことがわかった。これは，定 常状態では，応力は $G_{\mathrm{N}}$ からさほど大きくなっておら ず， $G_{\mathrm{eff}}$ の非線形性があまり関与していないからである。 クリープ測定から, 高応力下では $J_{\mathrm{e}}$ が増加しているこ とを指摘したが，この $J_{\mathrm{e}}$ の増加により非線形性が強く なっている可能性もある（ただし，通常の網目モデルで は，反対の結果になる)。したがって，流動誘起構造の 関与を考えるべきかもしれない。以上のように定常状態 からのクリープ回復と応力緩和について，現象論的には 問題ないと考えられるが，矛盾の全く無い分子論的描像 は，今後の検討課題である。

希薄溶液での特異な流動特性が, SIS（流動誘起のゲ ル構造）に関わっていると考えるならば，本研究での伸 びきり挙動と大いに関係しているようである。本実験で みた界面活性剂と塩が等モルの系では, 緩和時間の逆数 以上の高ずり速度での挙動は，ゲル化とみなせる。この 現象の分子論的な機構は今のところ不明であるが，希薄 溶液での SIS と同じで起源に由来すると考えることは， 不自然ではないであろう。希薄溶液では，例えば流動に よってミセルのマイグレーション（流動によって測定治 具内にミセルの濃度分布が生じること）が起これば，あ る時間を境にして部分的に準濃厚溶液になることが考え られる。高分子系でのマイグレーションはすでに実験的 に知られており ${ }^{26)}$ ，ひも状ミセル系でも同等の効果が存 在する可能性がある。

以上のように，ひも状ミセルのレオロジーには，「流 動誘起による構造形成」,「不安定化」,「流動誘起不均一 性」等の現代のレオロジーの最先端の問題が関与してい るようである。この中で，流動によるゲル化は，本研究 で紹介してきたように現象を通して定性的に理解するこ とができ，また，ひも状ミセル系のからみ合いの本質的 
な挙動と関係していると思われ, 今後その分子論的機構 の解明が望まれる。

\section{文献}

1) T. SHIKATA, H. HIRATA \& T. KOTAKA, Langmuir, 3, 1081-6 (1987).

2) T. SHIKATA, H. HIRATA \& T. KOTAKA, Langmuir, 4, 354-9 (1988).

3) T. SHIKATA, H. HIRATA \& T. KOTAKA, Langmuir, 5, 398-405 (1989).

4) T. SHIKATA, H. HIRATA \& T. KOTAKA, J. Physical Chem., 94, 3702-6 (1990).

5) M.E. CATES, Macromolecules, 20, 2289-96 (1987).

6) H. REHAGE \& H. HOFFMANN, J. Physical Chem., 92, 4712-9 (1988).

7) H. REHAGE \& H. HOFFMANN, Rheo. Acta, 21, 561 (1982).

8) Y. HU, S.Q. WANG \& A.M. JAMIESON, J. Rheol., 37, 531 (1993).

9) S.-Q. WANG, Y.T. HU \& A.M. JAMIESON, Rheology of Surfactant Solutions, (C.A. Herb, R.K. Prud'homme, Eds.) Am. Chem. Soc., p 278 (1994).

10) Y.T. HU \& E.F. MATTHYS, Rheo. Acta, 34, 450-60 (1995).

11) M.E. CATES \& M.S. TURNER, Europhys. Lett., 11, 681-6 (1990).

12) C.H. LIU \& D.J. PINE, Phys. Rev. Lett., 77, 2121-4 (1996).
13) R. BRUINSMA, W.M. GELBART \& A. BENSHAUL, $J$. Chem. Phys., 96, 7710-27 (1992).

14) I.A. KADOMA, C. YLITALO \& J.W. VAN EGMOND, Rheo. Acta, 36, 1-12 (1997).

15) T. SHIKATA, H. HIRATA, E. TAKATORI \& K. OSAKI, J. Non-Newtonian Fluid Mech., 28, 171-82 (1988).

16) T. INOUE, Y. INOUE \& H. WATANABE, Langmuir, 21, 1201-8 (2005).

17) T. SHIKATA, A. SAKAMOTO \& K. HANABUSA, Nihon Reoroji Gakkaishi, 32, 203-10 (2004).

18) R.G. LARSON, Constitutive Equations for Polymer Melts and Solutions, Butterworths, Sydney (1988).

19) L.R.G. TRELOAR, The Physics of Rubber Elasticity, Clarendon, Oxford (1958).

20) J.B. SAlmon, A. COlin, S. MANNEVille \& F. MOLINO, Phys. Rev. Lett., 90, Art. No. 228303 (2003).

21) J.P. DECRUPPE \& A. PONTON, European Phys. J. E, 10, 201-7 (2003).

22) E.K. WHEELER, P. IZU \& G.G. FULLER, Rheol. Acta, 35, 139-49 (1996).

23) I.A. KADOMA \& J.W. VANEGMOND, Langmuir, 13, 4551-61 (1997).

24) B.A. SCHUBERT, N.J. WAGNER, E.W. KALER \& S.R. RAGHAVAN, Langmuir, 20, 3564-73 (2004).

25) N. TOYODA, M. TAKENAKA, S. SAITO \& T. HASHIMOTO, Polymer, 42, 9193-203 (2001).

26) M.J. MACDONALD \& S.J. MULLER, J. Rheol., 40, 259-83 (1996). 